\title{
PELAKSANAAN PENDIDIKAN KARAKTER DI MADRASAH ALIYAH NEGERI 2 PALEMBANG
}

\begin{abstract}
Sukirman
Akmal Hawi

Alimron

Dosen Fakultas Ilmu

Tarbiyah dan

Keguruan UIN Raden

Fatah Palembang
\end{abstract}

\begin{abstract}
Moral degeneration has become a common phenomenon that plagues mankind in various parts of the world today, including in Indonesia. Various moral cases have occurred and adorned mass media almost all the time, ranging from cases of corruption, acts of violence, sexual harassment, pornography, prostitution, drug abuse, even murder. Since 2010 the Center for Curriculum and Bookkeeping has initiated a pioneering program of character education implementation in several districts / cities in all provinces in Indonesia.

This study uses a combination of quantitative and qualitative approaches. The data were collected using interviews and questionnaires. Data analysis is done descriptively in order to explain / describe the implementation of character education and the factors that become obstacles of its implementation.

In this research can be concluded that character education in MAN 2 Palembang has not been implemented maximally. Some things that have not been implemented related to the implementation of character education are: not all contextual learning strategies used, not all teachers use contextual learning strategies, there has been no specific effort to revitalize the activities of co-curricular and extra curricular, related to the integration of teachers in learning, there are still $33.33 \%$ of teachers are doing poorly (20.8\% are poor in learning planning, $25 \%$ on learning implementation aspects, and $4.2 \%$ on learning assessment aspects). Many factors constraints and support the implementation of character education in MAN 2 Palembang. The obstacles faced by the madrasah include: difficulty in carrying out routine activities, difficulties in performing spontaneous activities, and difficulties in conducting conditioning activities. While the constraints factor from the teacher side is the difficulty of integrating character education in the learning process, which include: difficulties linking character education with materials, methods, strategies, and learning media, difficulty determining the value of character to be achieved, difficulty measuring the attainment of character education in participants students, too many students per class, not all teachers and employees can be role models, the number of things that affect the character, as well as the many aspects of character that must be developed. While the factors supporting the implementation of character education in MAN 2 Palembang include: support of all madrasah residents, family environment, madrasah infrastructure facilities, budget, student association, and student motivation.
\end{abstract}




\section{Key words: Character Education}

\section{PENDAHULUAN}

Merosotnya moral sudah menjadi fenomena umum yang melanda umat manusia di berbagai belahan bumi saat ini, termasuk di Indonesia. Berbagai kasus moral telah terjadi dan menghiasi berbagai media massa hampir setiap saat, mulai dari kasus korupsi, tindak kekerasan, pelecehan seksual, pornografi, pelacuran, penyalahgunaan narkoba, bahkan pembunuhan.

Dalam menyikapi fenomena tersebut, Kementerian Pendidikan Nasional sejak tahun 2010 telah mencanangkan program pendidikan karakter. Bahkan salah satu dari enam program yang menjadi prioritas Kemendikbud adalah memperbaiki pendidikan agama, moral, dan pembentukan karakter. Tujuan pendidikan karakter adalah mendorong lahir dan tumbuhnya anak-anak dengan karakter yang baik, begitu tumbuh dalam karakter yang baik anak-anak akan tumbuh dengan kapasitas dan komitmennya untuk melakukan berbagai hal yang terbaik dan melakukan segalanya dengan benar, serta cenderung memiliki tujuan hidup (Kepennas, 2010: 11).

Dalam rangka lebih memperkuat pelaksanaan pendidikan karakter telah teridentifikasi 18 nilai yang bersumber dari agama, dasar negara Pancasila, budaya, dan tujuan pendidikan nasional, yaitu nilai: religius, jujur, toleransi, disiplin, kerja keras, kreatif, mandiri, demokratis, rasa ingin tahu, semangat kebangsaan, cinta tanah air, menghargai prestasi, bersahabat/komunikatif, cinta damai, gemar membaca, peduli lingkungan, peduli sosial, dan tanggung jawab. Meskipun telah terdapat 18 nilai pembentuk karakter bangsa, namun satuan pendidikan dapat menentukan prioritas pengembangannya dengan cara melanjutkan nilai prakondisi yang diperkuat dengan beberapa nilai yang diprioritaskan dari 18 nilai tersebut.

Berkaitan dengan pelaksanaan pendidikan karakter ini, sejak tahun 2010 Pusat Kurikulum dan Perbukuan telah melakukan program perintisan implementasi pendidikan karakter di beberapa Kabupaten/Kota di seluruh provinsi di Indonesia yang meliputi PAUD, SD, SMP, SMA, dan SMK. Pada tahun 2010 penerapan program sekolah rintisan kurikulum dan pendidikan karakter dilakukan 
di 16 daerah. Kemudian pada tahun 2011 bertambah 17 daerah dan pada tahun 2012 ditambahkan sebanyak 11 daerah, sehingga total daerah yang dijadikan sekolah rintisan sebanyak 44 daerah di Indonesia. Di Sumatera Selatan sendiri, sekolah rintisan awal pendidikan karakter adalah SDN 87, SDN 114, SMP Negeri 17 Palembang, SMA Negeri 1 Palembang, dan SMK Negeri 3 Palembang.

Meskipun kebijakan pendidikan karakter telah cukup lama dikeluarkan, namun realitas di lapangan menunjukkan bahwa masih banyak sekolah yang meskipun menyatakan telah melaksanakan pendidikan karakter namun pada kenyataannya belum sepenuhnya memenuhi pencapaian tujuan pendidikan karakter yang sesungguhnya. Kebanyakan sekolah hanya sebatas merencanakan beberapa instrumen pendidikan karakter, akan tetapi belum sampai pada tingkat pelaksanaan atau aplikasinya pada pendidikan karakter yang diharapkan.

Berkaitan dengan hal tersebut, perlu dilakukan penelitian pelaksanaan pendidikan karakter, khususnya di madrasah. Mengingat banyaknya jumlah madrasah yang ada, fokus penelitian ini hanya dibatasi pada MAN 2 Palembang dengan pertimbangan merupakan salah satu madrasah unggulan yang ada di kota Palembang.

\section{METODE PENELITIAN}

1. Pendekatan Penelitian

Penelitian ini menggunakan gabungan pendekatan kuantitatif dan kualitatif. Menurut Moleong (2000: v), pendekatan kuantitatif bertitik tolak dari objektivitas yang dibangun atas rumusan tentang situasi tertentu dan relevan dengan tujuan penelitian. Pendekatan kuantitatif digunakan untuk memperoleh data pelaksanaan pendidikan karakter dan faktor-faktor yang menjadi kendala pelaksanannya yang dikumpulkan melalui kuesioner. Sedangkan pendekatan kualitatif menurut Bogdan dan Taylor (1975: 5) merupakan penelitian yang menghasilkan data deskriptif berupa kata-kata tertulis atau lisan dari orang-orang dan perilaku yang dapat diamati. Pendekatan kualitatif digunakan untuk mengidentifikasi dan menggambarkan secara lebih komprehensif mengenai pelaksanaan pendidikan karakter dan faktor-faktor yang menjadi kendala pelaksanaannya yang dikumpulkan melalui wawancara dan studi dokumentasi.

2. Metode Penelitian 
Penelitian ini menggunakan metode deskriptif. Menurut Ali (1985:121), penelitian deskriptif bertujuan untuk membuat penggambaran tentang sesuatu keadaan secara objektif dalam suatu deskripsi situasi. Metode ini dipilih dengan harapan mendapatkan gambaran apa adanya dan utuh mengenai pendidikan karakter yang dilaksanakan di MAN 2 Palembang.

3. Responden Penelitian

Penelitian ini akan dilakukan di MAN 2 Palembang. Responden penelitiannya adalah Kepala Sekolah dan para guru.

\section{Teknik Pengumpulan Data}

Pengumpulan data dilakukan dengan menggunakan wawancara dan kuesioner. Wawancara digunakan untuk memperoleh data dari kepala madrasah tentang pendidikan karakter yang dilaksanakan dan faktor-faktor yang menjadi kendala pelaksanaannya. Sedangkan kuesioner digunakan untuk mengumpulkan data tentang pendidikan karakter yang dilaksanakan dan faktor-faktor yang menjadi kendala pelaksanaannya berdasarkan persepektif guru.

\section{Teknik Analisis Data}

Analisis data dilakukan secara deskriptif dengan tujuan untuk menjelaskan/mendeskripsikan pelaksanaan pendidikan karakter dan faktor-faktor yang menjadi kendala pelaksanaannya. Fungsi analisis ini sebetulnya adalah menyederhanakan atau meringkas kumpulan data sedemikian rupa sehingga kumpulan data tersebut berubah menjadi informasi yang berguna. Analisis data dilakukan secara kualitatif dan kuantitatif sesuai dengan data yang terkumpul.

\section{Prosedur Penelitian}

Penelitian ini dilakukan melalui empat tahapan, yaitu: 1) persiapan, 2) pengumpulan data, 3) pengolahan dan analisis data, serta 4) penulisan laporan. Pada tahap persiapan, dilakukan: a) penyusunan desain operasional penelitian dan b) penyusunan instrumen pengumpulan data. Pada tahap pengumpulan data dilakukan wawancara dan penyebaran kuesioner di MAN 2 Palembang. Pada tahap pengolahan dan analisis data, data yang terkumpul diolah dan dianalisis secara deskriptif. Pada tahap penulisan laporan, dilakukan penyusunan draft laporan penelitian, penyampaian/pemaparan hasil penelitian dalam Seminar Hasil 
Penelitian, revisi laporan sesuai masukan seminar, serta pengumpulan laporan penelitian final.

\section{HASIL PENELITIAN}

A. Pelaksanaan Pendidikan Karakter di MAN 2 Palembang

Data tentang pelaksanaan pendidikan karakter diperoleh melalui wawancara dengan kepala madrasah dan penyebaran kuesioner kepada para guru. Wawancara dengan kepala madrasah dilakukan pada tanggal 3 Oktober 2016. Berikut ini dideskripsikan pelaksanaan pendidikan karakter di MAN 2 Palembang berdasarkan teknik pengumpulan data yang digunakan.

\section{Hasil Wawancara}

Pelaksanaan pendidikan karakter di sekolah/madrasah seyogyanya diawali dengan kesepakatan antara semua pihak (kepala sekolah, wakil kepala, para guru, dan komite sekolah) tentang karakter yang akan diprioritaskan pengembangannya. Pemilihan nilai-nilai tersebut beranjak dari kepentingan dan kondisi satuan pendidikan masing-masing, yang dilakukan melalui analisis konteks, sehingga dalam implementasinya dimungkinkan terdapat perbedaan jenis nilai karakter yang dikembangkan antara satu sekolah dan atau daerah yang satu dengan lainnya. Implementasi nilai-nilai karakter yang akan dikembangkan dapat dimulai dari nilai-nilai yang esensial, sederhana, dan mudah dilaksanakan, seperti: bersih, rapi, nyaman, disiplin, sopan dan santun (Kemdiknas, 2011: 8).

Hasil wawancara dengan kepala madrasah menunjukkan bahwa pelaksanaan pendidikan karakter di MAN 2 Palembang diawali dengan kesepakatan bersama antara semua pihak tersebut. Namun dari 18 karakter yang ada dikembangkan, terbagi dalam beberapa tahap (misalnya tahun pertama 4 karakter dulu, tahun kedua 4 karakter berikutnya, dan seterusnya).

Selanjutnya, hasil wawancara juga menunjukkan bahwa pelaksanaan pendidikan karakter di MAN 2 Palembang dilakukan melalui ranah: pembelajaran (kegiatan pembelajaran), pengembangan budaya sekolah dan pusat kegiatan belajar, kegiatan ko-kurikuler dan atau kegiatan ekstrakurikuler, dan kegiatan keseharian di rumah dan di masyarakat. 
Terkait pelaksanaan pendidikan karakter melalui ranah pembelajaran (kegiatan pembelajaran), guru-guru di MAN 2 Palembang menggunakan strategi pembelajaran kontekstual. Akan tetapi, tidak semua strategi pembelajaran kontekstual digunakan. Strategi yang digunakan meliputi: pembelajaran berbasis masalah, pembelajaran kooperatif, pembelajaran pelayanan, dan pembelajaran berbasis kerja. Sedangkan strategi pembelajaran berbasis proyek tidak digunakan. Meski demikian, belum semua guru menggunakan strategi pembelajaran kontekstual. Karena untuk srategi pembelajaran berbasis masalah, baru $40 \%$ guru yang menggunakannya.

Terkait pelaksanaan pendidikan karakter melalui ranah pengembangan budaya sekolah dan pusat kegiatan belajar, MAN 2 Palembang melakukannya melalui kegiatan pengembangan diri, baik berupa kegiatan rutin, kegiatan spontan, keteladanan, dan pengkondisian. Untuk kegiatan rutin, bentuknya meliputi: upacara hari senin, upacara hari besar kenegaraan, piket kelas, shalat berjamaah, berdoa sebelum pelajaran dimulai dan diakhiri, mengucapkan salam apabila bertemu guru, tenaga pendidik, dan teman, serta tadarus sebelum jam pelajaran dimulai. Adapun kegiatan spontan yang dilaksanakan meliputi kegiatan mengumpulkan sumbangan ketika ada teman yang terkena musibah dan kegiatan mengumpulkan sumbangan untuk masyarakat ketika terjadi bencana. Bentuk keteladanan yang dilaksanakan adalah guru menjadi contoh pribadi yang bersih, rapi, ramah, dan supel. Selain itu, guru juga dituntut untuk menjadi teladan dalam berperilaku di sekolah maupun di masyarakat. Sedangkan bentuk pengkondisian yang dilaksanakan meliputi: mengkondisikan toilet yang bersih, adanya tempat sampah di setiap ruangan, halaman yang hijau dengan pepohonan, adanya poster kata-kata bijak yang dipajang di lorong sekolah dan di dalam kelas, mengelola konflik antar guru supaya tidak menjurus kepada perpecahan, serta menghilangkan konflik antar guru.

Terkait pelaksanaan pendidikan karakter melalui ranah kegiatan ko dan ekstra kurikuler, MAN 2 Palembang melaksanakan 14 (empat belas) kegiatan, diantaranya: pramuka, Palang Merah Indonesia (PMI), Paskibraka, Kelompok Ilmiah Remaja (KIR), Majelis Taklim, English Club, dan lain-lain. Selain itu, untuk mendukung pelaksanaan pendidikan karakter, dilakukan perencanaan dan 
evaluasi terhadap semua kegiatan yang dilaksanakan, namun sejauh ini belum ada upaya khusus untuk merevitalisasinya sehingga betul-betul diarahkan pada pencapaian pendidikan karakter yang diharapkan.

Terkait pelaksanaan pendidikan karakter melalui ranah kerjasama dengan pihak orang tua dan masyarakat, MAN 2 Palembang telah berupaya untuk mewujudkan keselarasan antara karakter yang dikembangkan di madrasah dengan pembiasaan di rumah dan masyarakat. Adapun bentuk upaya yang dilakukan adalah dengan mengundang orang tua/wali siswa dan komite madrasah untuk membahas permasalahan yang ada di madrasah, terutama yang berkaitan dengan pengembangan karakter siswa.

Berdasarkan hasil wawancara di atas, maka dapat dikatakan bahwa pendidikan karakter di MAN 2 Palembang masih belum terlaksana secara maksimal. Hal-hal yang telah dilaksanakan meliputi: a) pelaksanaan pendidikan karakter di sekolah ini diawali dengan kesepakatan antara semua pihak (kepala sekolah, wakil kepala, para guru, dan komite sekolah), b) pengembangan 18 karakter dilakukan secara bertahap, serta c) pelaksanaannya dilakukan baik melalui ranah pembelajaran (kegiatan pembelajaran), pengembangan budaya sekolah dan pusat kegiatan belajar, kegiatan ko-kurikuler dan atau kegiatan ekstrakurikuler, dan kegiatan keseharian di rumah dan di masyarakat. Beberapa hal yang belum dilaksanakan terkait pelaksanaan pendidikan karakter adalah: a) belum semua strategi pembelajaran kontekstual digunakan, b) belum semua guru menggunakan strategi pembelajaran kontekstual, serta c) belum ada upaya khusus untuk merevitalisasi kegiatan ko dan ekstra kurikuler sehingga betul-betul diarahkan pada pencapaian pendidikan karakter yang diharapkan.

\section{Hasil Kuesioner}

Jumlah responden guru MAN 2 Palembang yang mengisi dan mengembalikan kuesioner sebanyak 24 orang. Dari 24 orang responden tersebut, sebagian besar (16 orang atau 66,7\%) menyatakan telah menerapkan pendidikan karakter antara tahun 2011 s.d. 2015, bahkan cukup banyak (25\%) yang menyatakan telah menerapkannya sejak tahun 2010, dan hanya 8,3\% yang menyatakan baru menerapkannya pada tahun 2016. Gambaran selengkapnya 
keadaan responden berdasarkan tahun penerapan pendidikan karakter dapat dilihat pada tabel 1.

Tabel 1. Keadaan Responden Berdasarkan Tahun Penerapan Pendidikan Karakter

\begin{tabular}{|ll|r|r|r|r|}
\hline & Frequency & Percent & Valid Percent & Cumulative Percent \\
\hline Valid & 2016 & 2 & 8.3 & 8.3 & 8.3 \\
& $2011-2015$ & 16 & 66.7 & 66.7 & 75.0 \\
2010 & 6 & 25.0 & 25.0 & 100.0 \\
& 24 & 100.0 & 100.0 & \\
\hline
\end{tabular}

Dilihat dari pelatihan penerapan pendidikan karakter yang pernah diikuti, sebagian besar responden (14 orang atau 58,3\%) pernah mengikuti pelatihan penerapan pendidikan karakter hingga dua kali, bahkan 29,2\% mengikuti pelatihan sudah lebih dari dua kali, namun ada 1 orang $(4,2 \%)$ yang belum pernah mengikuti pelatihan yang dimaksud. Gambaran selengkapnya keadaan responden dilihat dari pelatihan penerapan pendidikan karakter yang pernah diikuti dapat dilihat pada tabel 2.

Tabel 2. Keadaan Responden Berdasarkan Pelatihan Penerapan Pendidikan Karakter yang Pernah Diikuti

\begin{tabular}{|l|r|r|r|r|}
\hline \multicolumn{7}{|c|}{ Mengikuti pelatihan } \\
\hline Valid $\quad$ Belum pernah & 1 & 4.2 & 4.2 & 4.2 \\
1 kali & 2 & 8.3 & 8.3 & 12.5 \\
2 kali & 14 & 58.3 & 58.3 & 70.8 \\
Lebih dari 2 kali & 7 & 29.2 & 29.2 & 100.0 \\
Total & 24 & 100.0 & 100.0 & Percent \\
\hline
\end{tabular}

Data kuesioner guru yang telah terkumpul selanjutnya dianalisis secara deskriptif guna memperoleh gambaran tentang pelaksanaan pendidikan karakter oleh guru di MAN 2 Palembang.

a. Gambaran Umum Pelaksanaan Pendidikan Karakter oleh Guru

Secara umum, hasil analisis deskriptif data pelaksanaan pendidikan karakter oleh guru diperoleh nilai mean 69, dengan median 72 dan modus 76, deviasi 
standar 7,223, serta skor minimum 56 dan skor maksimum 77. Statistik deskriptif data pelaksanaan pendidikan karakter oleh guru di MAN 2 Palembang selengkapnya dapat dilihat pada tabel 3.

\section{Tabel 3. Statistik Deskriptif Pelaksanaan Pendidikan Karakter Oleh Guru di MAN 2 Palembang}

\section{Statistics}

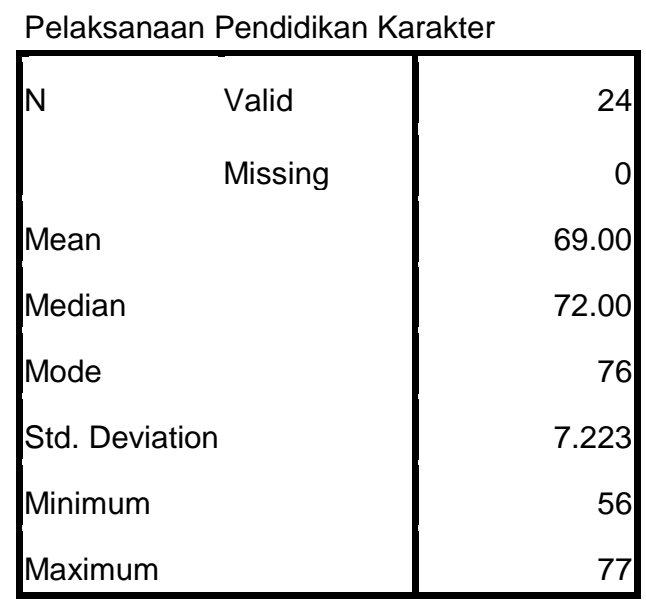

Selanjutnya dilakukan kategorisasi pelaksanaan pendidikan karakter dengan perhitungan: Batas Tinggi $=$ Mean +1 Deviasi Standar dan Batas Rendah $=$ Mean - 1 Deviasi Standar. Dengan demikian, tabel 4 menunjukkan interpretasi kategori pelaksanaan pendidikan karakter di MAN 2 Palembang.

Tabel 4. Distribusi Frekuensi Pelaksanaan Pendidikan Karakter oleh Guru di MAN 2 Palembang

\begin{tabular}{|l|r|r|r|r|}
\hline \multicolumn{7}{|c|}{ Pelaksanaan Pendidikan Karakter oleh Guru } \\
\hline & Frequency & Percent & Valid Percent & Cumulative Percent \\
\hline Valid $\quad$ Baik & 1 & 4.2 & 4.2 & 4.2 \\
& 15 & 62.5 & 62.5 & 66.7 \\
Cukup & 8 & 33.3 & 33.3 & 100.0 \\
Kurang & 24 & 100.0 & 100.0 & \\
\hline
\end{tabular}

Tabel 4 menunjukkan bahwa dari 24 guru yang menjadi sampel penelitian ini, sebagian besar (15 orang atau 62,5\%) telah melaksanakan pendidikan karakter dengan cukup baik, 8 orang $(33,33 \%)$ melaksanakannya dengan kurang baik, dan hanya 1 orang $(4,2 \%)$ yang melaksanakannya dengan baik. Dengan demikian, dapat dikatakan bahwa pelaksanaan pendidikan karakter oleh guru di MAN 2 
Palembang secara umum terkategori cukup baik, meski sebagian ada yang melaksanakannya dengan kurang baik. Dalam bentuk diagram, gambaran umum pelaksanaan pendidikan karakter oleh guru di MAN 2 Palembang disajikan pada gambar 1.

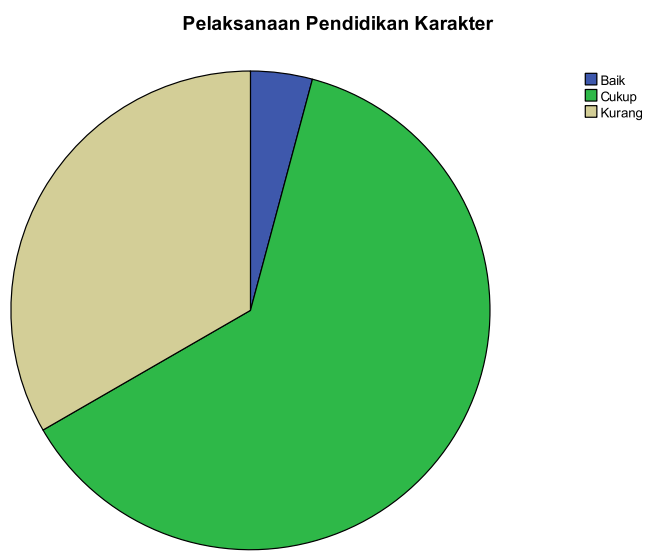

\section{Gambar 1. Pelaksanaan Pendidikan Karakter oleh Guru di MAN 2 Palembang}

b. Pelaksanaan Pendidikan Karakter oleh Guru Dilihat dari Masing-masing Aspek

1) Perencanaan Pembelajaran

Pada aspek perencanaan pembelajaran, hasil analisis data pelaksanaan pendidikan karakter oleh guru diperoleh nilai mean (rata-rata) sebesar 14,75 dengan median 15 dan modus 16, deviasi standar 1,751, serta skor minimum 10 dan skor maksimum 16. Gambaran selengkapnya statistik deskriptif pelaksanaan pendidikan karakter oleh guru pada aspek perencanaan pembelajaran dapat dilihat pada Tabel 5.

Selanjutnya dilakukan kategorisasi pelaksanaan pendidikan karakter oleh guru pada aspek perencanaan pembelajaran. Tabel 6 menunjukkan distribusi frekuensi pelaksanaan pendidikan karakter oleh guru pada aspek perencanaan pembelajaran di MAN 2 Palembang.

Tabel 6 menunjukkan bahwa dari 24 guru yang menjadi responden penelitian ini, sebagian besar (19 orang atau 79,2\%) menunjukkan tingkat pelaksanaan pendidikan karakter pada aspek perencanaan pembelajaran dalam kategori cukup baik, sisanya ada 5 orang (20,8\%) terkategori kurang baik, 
sedangkan yang terkategori baik tidak ada sama sekali. Dengan demikian, dapat dikatakan bahwa tingkat pelaksanaan pendidikan karakter oleh guru pada aspek perencanaan pembelajaran masih belum maksimal. Dalam bentuk diagram, gambaran umum pelaksanaan pendidikan karakter oleh guru pada aspek perencanaan pembelajaran di MAN 2 Palembang disajikan pada gambar 2.

Tabel 5. Statistik Deskriptif Pelaksanaan Pendidikan Karakter oleh Guru pada Aspek Perencanaan Pembelajaran

Statistics

Perencanaan Pembelajaran

\begin{tabular}{|c|c|c|}
\hline$N$ & Valid & 24 \\
\hline & Missing & 0 \\
\hline \multicolumn{2}{|c|}{ Mean } & 14.75 \\
\hline \multicolumn{2}{|c|}{ Median } & 15.00 \\
\hline \multicolumn{2}{|c|}{ Mode } & 16 \\
\hline \multicolumn{2}{|c|}{ Std. Deviation } & 1.751 \\
\hline \multicolumn{2}{|c|}{ Minimum } & 10 \\
\hline \multicolumn{2}{|c|}{ Maximum } & 16 \\
\hline
\end{tabular}

Tabel 6. Distribusi Frekuensi Pelaksanaan Pendidikan Karakter oleh Guru pada Aspek Perencanaan Pembelajaran di MAN 2 Palembang

\begin{tabular}{|c|c|c|c|c|c|}
\hline \multicolumn{6}{|c|}{ Perencanaan Pembelajaran } \\
\hline & & Frequency & Percent & Valid Percent & $\begin{array}{c}\text { Cumulative } \\
\text { Percent }\end{array}$ \\
\hline \multirow[t]{3}{*}{ Valid } & Cukup & 19 & 79.2 & 79.2 & 79.2 \\
\hline & Kurang & 5 & 20.8 & 20.8 & 100.0 \\
\hline & Total & 24 & 100.0 & 100.0 & \\
\hline
\end{tabular}




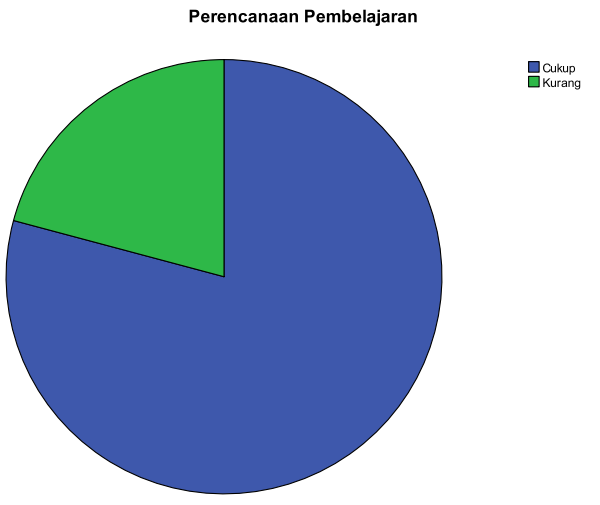

Gambar 2. Pelaksanaan Pendidikan Karakter oleh Guru pada Aspek Perencanaan Pembelajaran di MAN 2 Palembang

2) Pelaksanaan Pembelajaran

Pada aspek pelaksanaan pembelajaran, hasil analisis data pelaksanaan pendidikan karakter oleh guru diperoleh nilai mean (rata-rata) sebesar 49,54 dengan median 51 dan modus 55, deviasi standar 6,359, serta skor minimum 37 dan skor maksimum 56. Gambaran selengkapnya statistik deskriptif pelaksanaan pendidikan karakter oleh guru pada aspek pelaksanaan pembelajaran dapat dilihat pada Tabel 7.

\section{Tabel 7. Statistik Deskriptif Pelaksanaan Pendidikan Karakter oleh Guru pada Aspek Pelaksanaan Pembelajaran}

\section{Statistics}

Pelaksanaan Pembelajaran

\begin{tabular}{|l|r|}
\hline N $\quad$ Valid & 24 \\
& Missing \\
Mean & 0 \\
Median & 49.54 \\
Mode & 51.00 \\
Std. Deviation & 55 \\
Minimum & 6.359 \\
Maximum & 37 \\
\hline
\end{tabular}

Selanjutnya dilakukan kategorisasi pelaksanaan pendidikan karakter oleh guru pada aspek pelaksanaan pembelajaran. Tabel 8 menunjukkan distribusi frekuensi pelaksanaan pendidikan karakter oleh guru pada aspek pelaksanaan pembelajaran di MAN 2 Palembang. 
Tabel 8. Distribusi Frekuensi Pelaksanaan Pendidikan Karakter oleh Guru pada Aspek Pelaksanaan Pembelajaran di MAN 2 Palembang

\begin{tabular}{|r|r|r|r|r|}
\hline & & & & \multicolumn{2}{c|}{$\begin{array}{c}\text { Pumulative } \\
\text { Percent }\end{array}$} \\
& Frequency & Percent & Valid Percent & Pembelajaran \\
\hline Valid $\quad$ Baik & 3 & 12.5 & 12.5 & 12.5 \\
& Cukup & 62.5 & 62.5 & 75.0 \\
Kurang & 6 & 25.0 & 25.0 & 100.0 \\
Total & 24 & 100.0 & 100.0 & \\
\hline
\end{tabular}

Tabel 8 menunjukkan bahwa dari 24 guru yang menjadi responden penelitian ini, sebagian besar (15 orang atau 62,5\%) menunjukkan tingkat pelaksanaan pendidikan karakter pada aspek pelaksanaan pembelajaran dalam kategori cukup baik, sisanya ada 6 orang $(25 \%)$ terkategori kurang baik dan 3 orang $(12,5 \%)$ terkategori baik. Dengan demikian, dapat dikatakan bahwa tingkat pelaksanaan pendidikan karakter oleh guru pada aspek pelaksanaan pembelajaran masih belum maksimal. Dalam bentuk diagram, gambaran umum pelaksanaan pendidikan karakter oleh guru pada aspek pelaksanaan pembelajaran di MAN 2 Palembang disajikan pada gambar 3.

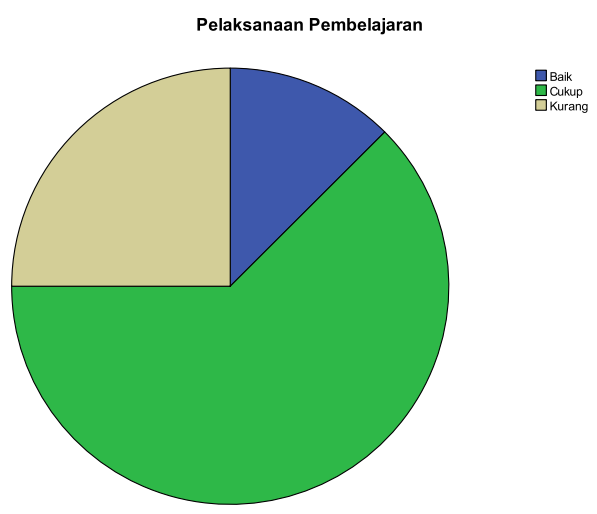

\section{Gambar 3. Pelaksanaan Pendidikan Karakter oleh Guru pada Aspek Pelaksanaan Pembelajaran di MAN 2 Palembang}

3) Penilaian Pembelajaran

Pada aspek penilaian pembelajaran, hasil analisis data pelaksanaan pendidikan karakter oleh guru diperoleh nilai mean (rata-rata) sebesar 4,71 dengan median 5 dan modus 5 , deviasi standar 0,751, serta skor minimum 3 dan skor 
maksimum 6. Gambaran selengkapnya statistik deskriptif pelaksanaan pendidikan karakter oleh guru pada aspek penilaian pembelajaran dapat dilihat pada Tabel 9.

Tabel 9. Statistik Deskriptif Pelaksanaan Pendidikan Karakter oleh Guru pada Aspek Penilaian Pembelajaran

Statistics

Penilaian Pembelajaran
\begin{tabular}{|l|r|}
\hline N $\quad$ Valid & 24 \\
\multicolumn{1}{|c|}{ Missing } & 0 \\
Mean & 4.71 \\
Median & 5.00 \\
Mode & 5 \\
Std. Deviation & .751 \\
Minimum & 3 \\
Maximum & 6 \\
\hline
\end{tabular}

Selanjutnya dilakukan kategorisasi pelaksanaan pendidikan karakter oleh guru pada aspek penilaian pembelajaran. Tabel 10 menunjukkan distribusi frekuensi pelaksanaan pendidikan karakter oleh guru pada aspek penilaian pembelajaran di MAN 2 Palembang.

Tabel 10. Distribusi Frekuensi Pelaksanaan Pendidikan Karakter oleh Guru pada Aspek Penilaian Pembelajaran di MAN 2 Palembang

\begin{tabular}{|c|c|c|c|c|c|}
\hline \multicolumn{6}{|c|}{ Penilaian Pembelajaran } \\
\hline & & Frequency & Percent & Valid Percent & $\begin{array}{c}\text { Cumulative } \\
\text { Percent }\end{array}$ \\
\hline \multirow[t]{4}{*}{ Valid } & Baik & 3 & 12.5 & 12.5 & 12.5 \\
\hline & Cukup & 20 & 83.3 & 83.3 & 95.8 \\
\hline & Kurang & 1 & 4.2 & 4.2 & 100.0 \\
\hline & Total & 24 & 100.0 & 100.0 & \\
\hline
\end{tabular}

Tabel 10 menunjukkan bahwa dari 24 guru yang menjadi responden penelitian ini, sebagian besar (20 orang atau 83,3\%) menunjukkan tingkat pelaksanaan pendidikan karakter pada aspek penilaian pembelajaran dalam kategori cukup baik, sisanya ada 3 orang (12,5\%) terkategori baik dan 1 orang 
$(4,2 \%)$ terkategori kurang baik. Dengan demikian, dapat dikatakan bahwa tingkat pelaksanaan pendidikan karakter oleh guru pada aspek penilaian pembelajaran masih belum maksimal. Dalam bentuk diagram, gambaran umum pelaksanaan pendidikan karakter oleh guru pada aspek penilaian pembelajaran di MAN 2 Palembang disajikan pada gambar 4.

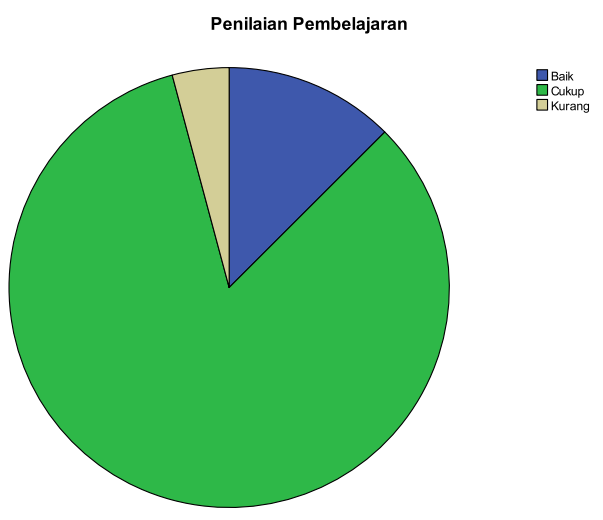

Gambar 4. Pelaksanaan Pendidikan Karakter oleh Guru pada Aspek Penilaian Pembelajaran di MAN 2 Palembang

Berdasarkan hasil kuesioner di atas, maka dapat dikatakan bahwa baik secara umum maupun dilihat dari masing-masing aspek, pelaksanaan pendidikan karakter oleh guru MAN 2 Palembang masih belum maksimal. Secara umum, dari 24 guru yang menjadi sampel penelitian ini, sebagian besar $(62,5 \%)$ telah melaksanakan pendidikan karakter dengan cukup baik, 33,33\% melaksanakannya dengan kurang baik, dan 4,2\% yang melaksanakannya dengan baik. Secara khusus, dilihat dari masing-masing aspek kondisinya tidak jauh berbeda, sebagian besar guru melaksanakan pendidikan karakter dengan cukup baik. Pada aspek perencanaan pembelajaran, sebagian besar (79,2\%) menunjukkan tingkat pelaksanaan pendidikan karakter pada aspek perencanaan pembelajaran dalam kategori cukup baik, sisanya ada 20,8\% terkategori kurang baik, sedangkan yang terkategori baik tidak ada sama sekali. Pada aspek pelaksanaan pembelajaran, sebagian besar $(62,5 \%)$ menunjukkan tingkat pelaksanaan pendidikan karakter pada aspek pelaksanaan pembelajaran dalam kategori cukup baik, sisanya ada $25 \%$ terkategori kurang baik dan 12,5\% terkategori baik. Pada aspek penilaian pembelajaran, sebagian besar $(83,3 \%)$ menunjukkan tingkat pelaksanaan pendidikan karakter pada aspek penilaian pembelajaran dalam kategori cukup baik, sisanya ada $12,5 \%$ terkategori baik dan $4,2 \%$ terkategori kurang baik. 
Hasil wawancara dan kuesioner di atas menunjukkan bahwa pendidikan karakter di MAN 2 Palembang belum terlaksana secara maksimal. Beberapa hal yang belum dilaksanakan terkait pelaksanaan pendidikan karakter adalah: a) belum semua strategi pembelajaran kontekstual digunakan, b) belum semua guru menggunakan strategi pembelajaran kontekstual, c) belum ada upaya khusus untuk merevitalisasi kegiatan ko dan ekstra kurikuler, d) terkait pengintegrasiannya oleh guru dalam pembelajaran, masih ada 33,33\% guru melaksanakannya dengan kurang baik (20,8\% terkategori kurang baik pada aspek perencanaan pembelajaran, 25\% pada aspek pelaksanaan pembelajaran, dan 4,2\% pada aspek penilaian pembelajaran).

Hasil penelitian ini sejalan dengan penelitian yang dilakukan oleh Suhartinah (2012) yang menunjukkan bahwa: 1) perencanaan program pendidikan karakter sudah tersusun dengan baik; akan tetapi masih terdapat kelemahan yaitu belum mencantumkan dan menuliskan metode serta langkah-langkah secara eksplisit; 2) pelaksanaan pendidikan karakter sudah berjalan sangat baik yang ditandai dengan terealisasinya semua nilai karakter yang telah direncanakan serta terjadinya perubahan sikap positif pada anak; dan 3) penilaian sudah terlaksana dengan optimal dan berkesinambungandi mana pelaksanaannya dilakukan secara bertahap, mulai dari penilaian harian, mingguan, bulanan, tri wulan dan semester dengan teknis pelaporan narasi dan format ceklis.

Hasil penelitian ini menunjukkan bahwa pendidikan karakter di MAN 2 Palembang belum terlaksana secara maksimal, salah satu indikatornya adalah belum semua guru menggunakan strategi pembelajaran kontekstual. Elkind (2004) menyatakan bahwa pendidikan karakter ialah segala sesuatu yang dilakukan guru, yang mampu mempengaruhi karakter peserta didik. Guru membantu membentuk watak peserta didik. Hal ini mencakup keteladanan bagaimana perilaku guru, cara guru berbicara atau menyampaikan materi, bagaimana guru bertoleransi, dan berbagai hal terkait lainnya. Stategi kontekstual. Menurut Solomon dkk (1990) dalam kegiatan pembelajaran di kelas, masalah moral yang timbul biasanya mencakup situasi di mana siswa ditantang mewujudkan adanya keseimbangan secara bersamaan antara hak dan tanggung jawab dirinya dengan hak dan tanggung jawab orang lain. Siswa menunjukkan perkembangan moral secara 
dewasa apabila memiliki kemauan dan kemampuan perjuang mencari keseimbangan antara kebutuhan diri dan kebutuhan lain. Pengelolaan pembelajaran menimbulkan berbagai situasi di mana siswa harus membuat keputusan tentang kebutuhan hak dirinya dengan hak dan tanggung jawab siswa lainnya. Kejadian ini sering timbul, maka guru harus menentukan strategi yang memadai untuk menangani isu-isu moral dan pengembangan karakter siswa melalui pembelajaran yang diangkat dari situasi kehidupan nyata.

\section{B. Faktor-faktor Kendala Pelaksanaan Pendidikan Karakter di MAN 2 Palembang}

Belum maksimalnya pelaksanaan pendidikan karakter disebabkan oleh adanya beberapa faktor yang menjadi kendala. Data tentang faktor-faktor yang menjadi kendala pelaksanaan pendidikan karakter di MAN 2 Palembag juga diperoleh melalui wawancara dengan kepala madrasah dan penyebaran kuesioner kepada para guru. Wawancara dengan kepala madrasah dilakukan pada tanggal 3 Oktober 2016. Berikut ini dideskripsikan data faktor-faktor kendala pelaksanaan pendidikan karakter di MAN 2 Palembang berdasarkan teknik pengumpulan data yang digunakan.

\section{Hasil Wawancara}

Hasil wawancara dengan kepala madrasah menunjukkan bahwa belum maksimalnya pelaksanaan pendidikan karakter di MAN 2 Palembang disebabkan beberapa faktor kendala, diantaranya adalah faktor guru. Menurut kepala madrasah, terkadang para guru mengalami kesulitan dalam mengintegrasikan pendidikan karakter dalam proses pembelajaran. Faktor kendala lainnya adalah kesulitan dalam melaksanakan kegiatan rutin seperti upacara hari Senin dan hari besar kenegaraan, piket kelas, shalat berjamaah, dll., kesulitan dalam melaksanakan kegiatan spontan seperti mengumpulkan sumbangan ketika ada yang terkena musibah, dan kesulitan dalam melaksanakan kegiatan pengkondisian lingkungan fisik maupun non fisik guna terciptanya iklim yang kondusif bagi keberhasilan implementasi pendidikan karakter.

Disamping itu, menurut kepala MAN 2 Palembang, keberhasilan pelaksanaan pendidikan karakter tidak terlepas dari dukungan seluruh warga madrasah, lingkungan keluarga siswa, serta sarana prasarana yang dimiliki oleh 
madrasah. Hal lain yang tidak kalah pentingnya adalah besarnya anggaran madrasah terkait pelaksanaan pendidikan karakter.

Berdasarkan hasil wawancara di atas, dapat dikatakan bahwa faktor kendala pelaksanaan pendidikan karakter di MAN 2 Palembang meliputi kesulitan guru dalam mengintegrasikan pendidikan karakter dalam proses pembelajaran, kesulitan dalam melaksanakan kegiatan rutin, kesulitan dalam melaksanakan kegiatan spontan, dan kesulitan dalam melaksanakan kegiatan pengkondisian lingkungan yang kondusif bagi keberhasilan implementasi pendidikan karakter. Sedangkan faktor pendukungnya meliputi dukungan seluruh warga madrasah, lingkungan keluarga, sarana prasarana madrasah, serta anggaran madrasah terkait pelaksanaan pendidikan karakter.

\section{Hasil Kuesioner}

Sejalan dengan hasil wawancara, hasil kuesioner menunjukkan bahwa belum maksimalnya pelaksanaan pendidikan di MAN 2 Palembang salah satunya dipengaruhi oleh faktor dari guru itu sendiri. Hasil kuesioner yang diisi oleh guru menunjukkan bahwa semua guru mengalami kesulitan dalam mengintegrasikan pendidikan karakter dalam proses pembelajaran, baik dalam mengaitkan pendidikan karakter dengan materi pembelajaran, metode pembelajaran, strategi pembelajaran, maupun media pembelajaran. Tabel 11 menunjukkan distribusi frekuensi jawaban responden guru di MAN 2 Palembang tentang komponen pembelajaran yang sulit dikaitkan dengan pendidikan karakter.

Tabel 11. Distribusi Frekuensi Jawaban Responden tentang Komponen Pembelajaran yang Sulit Dikaitkan dengan Pendidikan Karakter

\begin{tabular}{|c|c|c|c|c|c|}
\hline & & Frequency & Percent & $\begin{array}{c}\text { Valid } \\
\text { Percent }\end{array}$ & $\begin{array}{c}\text { Cumulative } \\
\text { Percent }\end{array}$ \\
\hline \multirow[t]{5}{*}{ Valid } & Materi & 3 & 12.5 & 12.5 & 12.5 \\
\hline & Metode & 9 & 37.5 & 37.5 & 50.0 \\
\hline & Metode, strategi, media & 4 & 16.7 & 16.7 & 66.7 \\
\hline & Strategi & 2 & 8.3 & 8.3 & 75.0 \\
\hline & Strategi dan media & 4 & 16.7 & 16.7 & 91.7 \\
\hline
\end{tabular}




\begin{tabular}{|l|r|r|r|r|}
\hline Media & 2 & 8.3 & 8.3 & 100.0 \\
Total & 24 & 100.0 & 100.0 & \\
\hline
\end{tabular}

Tabel 11 menunjukkan bahwa dari 24 guru yang menjadi responden penelitian ini, 4 orang $(16,7 \%)$ mengalami kesulitan dalam mengkaitkan pendidikan karakter dengan metode, strategi, dan media pembelajaran, 4 orang $(16,7 \%)$ kesulitan mengaitkannya dengan strategi dan media pembelajaran, 9 orang $(37,5 \%)$ kesulitan mengaitkannya hanya dengan metode pembelajaran, 3 orang $(12,5 \%)$ hanya dengan materi pembelajaran, 2 orang $(8,3 \%)$ hanya dengan strategi pembelajaran, dan 2 orang $(8,3 \%)$ hanya dengan media pembelajaran. Dengan demikian, dapat dikatakan bahwa kesulitan mengaitkan pendidikan karakter dengan komponen pembelajaran menjadi salah satu kendala bagi semua guru MAN II Palembang dalam melaksanakan pendidikan karakter.

Faktor lain yang terkadang menjadi kendala bagi guru dalam melaksanakan pendidikan karakter di MAN 2 Palembang adalah kesulitan dalam menentukan nilai karakter yang akan dicapai. Tabel 12 menunjukkan distribusi frekuensi jawaban responden guru tentang kesulitan menentukan nilai karakter yang akan dicapai.

\section{Tabel 12. Distribusi Frekuensi Jawaban Responden tentang Kesulitan Menentukan Nilai Karakter yang akan Dicapai}

\begin{tabular}{|c|c|c|c|c|c|}
\hline & & Frequency & Percent & Valid Percent & $\begin{array}{c}\text { Cumulative } \\
\text { Percent }\end{array}$ \\
\hline \multirow[t]{5}{*}{ Valid } & Selalu & 1 & 4.2 & 4.2 & 4.2 \\
\hline & Seringkali & 3 & 12.5 & 12.5 & 16.7 \\
\hline & Kadang-kadang & 19 & 79.2 & 79.2 & 95.8 \\
\hline & Tidak pernah & 1 & 4.2 & 4.2 & 100.0 \\
\hline & Total & 24 & 100.0 & 100.0 & \\
\hline
\end{tabular}

Tabel 12 menunjukkan bahwa dari 24 guru yang menjadi responden penelitian ini, 19 orang $(79,2 \%)$ kadang-kadang mengalami kesulitan menentukan nilai karakter yang akan dicapai, 3 orang $(12,5 \%)$ seringkali mengalami kesulitan, 
1 orang $(4,2 \%)$ selalu mengalami kesulitan, dan 1 orang $(4,2 \%)$ tidak pernah mengalami kesulitan. Dengan demikian, dapat dikatakan bahwa kesulitan menentukan nilai karakter yang akan dicapai menjadi salah satu kendala bagi sebagian besar guru di MAN II Palembang dalam melaksanakan pendidikan karakter.

Faktor kendala berikutnya adalah kesulitan mengukur ketercapaian pendidikan karakter pada diri peserta didik. Tabel 13 menunjukkan distribusi frekuensi jawaban responden guru MAN II Palembang tentang kesulitan mereka dalam mengukur ketercapaian pendidikan karakter pada diri peserta didik.

Tabel 13 menunjukkan bahwa dari 24 guru yang menjadi responden penelitian, 21 orang $(87,5 \%)$ kadang-kadang mengalami kesulitan mengukur ketercapaian pendidikan karakter pada diri peserta didik, 1 orang $(4,2 \%)$ selalu kesulitan, dan 2 orang $(8,3 \%)$ tidak pernah mengalami kesulitan. Dengan demikian, dapat dikatakan bahwa kesulitan mengukur ketercapaian pendidikan karakter pada diri peserta didik menjadi salah satu kendala bagi sebagian besar guru dalam melaksanakan pendidikan karakter.

Tabel 13. Distribusi Frekuensi Jawaban Responden tentang Kesulitan Mengukur Ketercapaian Pendidikan Karakter pada Diri Peserta Didik

\begin{tabular}{|l|r|r|r|r|}
\hline & & & & \multicolumn{2}{c|}{$\begin{array}{c}\text { Cumulative } \\
\text { Percent }\end{array}$} \\
\hline Valid & Frequency & Percent & Valid Percent & 4.2 \\
& 1 & 4.2 & 4.2 & 4.2 \\
& Seringkali & 0.0 & 0.0 & 4.2 \\
Kadang-kadang & 21 & 87.5 & 87.5 & 91.7 \\
Tidak pernah & 2 & 8.3 & 8.3 & 100.0 \\
Total & 24 & 100.0 & 100.0 & \\
\hline
\end{tabular}

Selain yang telah dikemukakan, faktor kendala lain yang dihadapi guru MAN II Palembang dalam melaksanakan pendidikan karakter adalah jumlah siswa per kelas yang terlalu banyak, belum semua guru dan karyawan bisa menjadi teladan, banyaknya hal yang mempengaruhi karakter, serta banyaknya aspek karakter yang harus dikembangkan. Tabel 14 menunjukkan distribusi 
frekuensi jawaban responden guru MAN II Palembang tentang kendala lainnya dalam pelaksanaan pendidikan karakter.

Tabel 14 menunjukkan bahwa dari 24 guru yang menjadi responden penelitian, 6 orang $(25 \%)$ mengemukakan bahwa kendala lain pelaksanaan pendidikan karakter adalah jumlah siswa per kelas yang terlalu banyak, 1 orang $(4,2 \%)$ menyatakan belum semua guru dan karyawan bisa menjadi teladan sebagai kendala lainnya, 1 orang $(4,2 \%)$ menyatakan bahwa faktor kendala lainnya adalah terlalu banyaknya jumlah siswa per kelas, banyaknya hal yang mempengaruhi karakter, dan banyaknya aspek karakter yang harus dikembangkan.

\section{Tabel 14. Distribusi Frekuensi Jawaban Responden tentang Faktor Kendala Lainnya dalam Pelaksanaan Pendidikan Karakter}

\begin{tabular}{|c|c|c|c|c|c|}
\hline & & Frequency & Percent & $\begin{array}{c}\text { Valid } \\
\text { Percent }\end{array}$ & $\begin{array}{c}\text { Cumulative } \\
\text { Percent }\end{array}$ \\
\hline Valid & $\begin{array}{l}\text { Tidak menjawab } \\
\text { Jumlah siswa per kelas terlalu banyak } \\
\text { Belum semua guru dan karyawan yg } \\
\text { bisa menjadi teladan } \\
\text { Jumlah siswa per kelas terlalu } \\
\text { banyak, banyak hal mempengaruhi } \\
\text { karakter \& banyaknya aspek karakter } \\
\text { yang dikembangkan } \\
\text { Total }\end{array}$ & $\begin{array}{c}16 \\
6 \\
1\end{array}$ & $\begin{array}{r}66,6 \\
25.0 \\
4.2 \\
4.2\end{array}$ & $\begin{array}{r}66,6 \\
25.0 \\
4.2\end{array}$ & $\begin{array}{r}66,6 \\
91.6 \\
95.8\end{array}$ \\
\hline
\end{tabular}

Selain berbagai faktor kendala, keberhasilan pelaksanaan pendidikan karakter juga dipengaruhi oleh faktor pendukung. Adapun beberapa faktor pendukung pelaksanaan pendidikan karakter di MAN II Palembang dalam proses pembelajaran antara lain adalah dukungan seluruh warga madrasah, sarana dan prasarana pendukung, lingkungan keluarga, dan pergaulan siswa. Tabel 15 menunjukkan distribusi frekuensi jawaban responden guru MAN II Palembang tentang faktor pendukung pelaksanaan pendidikan karakter dalam proses pembelajaran.

Tabel 15 menunjukkan bahwa dari 24 guru yang menjadi responden penelitian, 13 orang $(54,2 \%)$ menyatakan bahwa satu-satunya faktor pendukung 
pelaksanaan pendidikan karakter dalam proses pembelajaran adalah dukungan seluruh warga sekolah, 4 orang $(16,7 \%)$ menyatakan sarana dan prasarana madrasah sebagai satu-satunya faktor pendukung, 4 orang $(16,7 \%)$ menyatakan dukungan seluruh warga madrasah, lingkungan keluarga, dan pergaulan siswa sebagai faktor-faktor pendukung, 1 orang $(4,2 \%)$ menyatakan dukungan seluruh warga madrasah dan lingkungan keluarga sebagai faktor pendukung, 1 orang $(4,2 \%)$ menyatakan lingkungan keluarga dan sarana prasarana madrasah sebagai faktor pendukung, serta 1 orang $(4,2 \%)$ menyatakan bahwa dukungan seluruh warga madrasah, lingkungan keluarga, dan sarana prasarana madrasah sebagai faktor-faktor pendukung pelaksanaan pendidikan karakter.

Tabel 15. Distribusi Frekuensi Jawaban Responden tentang Faktor Pendukung Pelaksanaan Pendidikan Karakter dalam Proses Pembelajaran

\begin{tabular}{|c|c|c|c|c|c|}
\hline \multicolumn{6}{|c|}{ Faktor pendukung } \\
\hline & & Frequency & Percent & $\begin{array}{c}\text { Valid } \\
\text { Percent }\end{array}$ & $\begin{array}{c}\text { Cumulative } \\
\text { Percent }\end{array}$ \\
\hline Valid & $\begin{array}{l}\text { Seluruh warga madrasah } \\
\text { Sarana prasarana madrasah } \\
\text { Seluruh warga madrasah, } \\
\text { lingkungan keluarga \& } \\
\text { pergaulan siswa } \\
\text { Seluruh warga madrasah \& } \\
\text { lingkungan keluarga } \\
\text { Lingkungan keluarga \& sarana } \\
\text { prasarana madrasah } \\
\text { Seluruh warga madrasah, } \\
\text { lingkungan keluarga \& sarana } \\
\text { prasarana } \\
\text { Total }\end{array}$ & $\begin{array}{r}13 \\
4 \\
4 \\
1\end{array}$ & $\begin{array}{r}4.2 \\
4.2 \\
100.0\end{array}$ & $\begin{array}{r}54.2 \\
16.6 \\
16.6\end{array}$ & $\begin{array}{l}54.2 \\
70.8 \\
87.4\end{array}$ \\
\hline
\end{tabular}

Selain faktor pendukung yang sudah disebutkan, faktor lain yang memiliki peran penting dalam pelaksanaan pendidikan karakter adalah motivasi peserta didik. Tabel 15 menunjukkan distribusi frekuensi jawaban responden guru MAN 
II Palembang tentang peran motivasi peserta didik dalam pelaksanaan pendidikan karakter.

Tabel 16 menunjukkan bahwa dari 24 guru yang menjadi responden penelitian, 12 orang (50\%) menyatakan bahwa motivasi peserta didik selalu berperan dalam pelaksanaan pendidikan karakter, 6 orang (25\%) menyatakan seringkali berperan, 6 orang (25\%) menyatakan kadang-kadang berperan, dan tidak ada yang menyatakan tidak berperan sama sekali. Dengan demikian, dapat dikatakan bahwa semua guru berpandangan bahwa keberhasilan pelaksanaan pendidikan karakter tidak terlepas dari peran motivasi peserta didik.

Tabel 16. Distribusi Frekuensi Jawaban Responden tentang Peran Motivasi Peserta Didik dalam Pelaksanaan Pendidikan Karakter

\begin{tabular}{|ll|r|r|r|r|}
\hline & & Peran motivasi peserta didik & \\
\hline Valid Selalu & Frequency & Percent & Valid Percent & Cumulative Percent \\
& 12 & 50.0 & 50.0 & 50.0 \\
& Seringkali & 6 & 25.0 & 25.0 & 75.0 \\
Kadang-kadang & 6 & 25.0 & 25.0 & 100.0 \\
& 24 & 100.0 & 100.0 & \\
\hline
\end{tabular}

Berdasarkan hasil kuesioner di atas, dapat dikatakan bahwa faktor-faktor kendala pelaksanaan pendidikan karakter bagi guru meliputi kesulitan dalam mengintegrasikan pendidikan karakter dalam proses pembelajaran, baik dengan materi, metode, strategi, maupun media pembelajaran, kesulitan dalam menentukan nilai karakter yang akan dicapai, kesulitan mengukur ketercapaian pendidikan karakter pada diri peserta didik, jumlah siswa per kelas yang terlalu banyak, belum semua guru dan karyawan bisa menjadi teladan, banyaknya hal yang mempengaruhi karakter, serta banyaknya aspek karakter yang harus dikembangkan. Sedangkan faktor pendukung pelaksanaan pendidikan karakter oleh guru meliputi dukungan seluruh warga madrasah, sarana dan prasarana pendukung, lingkungan keluarga, dan pergaulan siswa, serta motivasi siswa.

Hasil wawancara dan kuesioner yang telah diuraikan di atas menunjukkan bahwa ada banyak faktor yang mempengaruhi pelaksanaan pendidikan karakter di MAN 2 Palembang, baik berupa faktor kendala maupun faktor pendukung. Faktor kendala dari sisi madrasah meliputi: 1) kesulitan dalam melaksanakan kegiatan 
rutin, 2) kesulitan dalam melaksanakan kegiatan spontan, dan 3) kesulitan dalam melaksanakan kegiatan pengkondisian. Sedangkan faktor kendala dari sisi guru adalah kesulitan mengintegrasikan pendidikan karakter dalam proses pembelajaran, yang meliputi: 1) kesulitan mengaitkan pendidikan karakter baik dengan materi, metode, strategi, maupun media pembelajaran, 2) kesulitan menentukan nilai karakter yang akan dicapai, 3) kesulitan mengukur ketercapaian pendidikan karakter pada diri peserta didik, 4) jumlah siswa per kelas yang terlalu banyak, 5) belum semua guru dan karyawan bisa menjadi teladan, 6) banyaknya hal yang mempengaruhi karakter, serta 7) banyaknya aspek karakter yang harus dikembangkan. Sementara faktor pendukung pelaksanaan pendidikan karakter di MAN 2 Palembang meliputi: 1) dukungan seluruh warga madrasah, 2) lingkungan keluarga, 3) sarana prasarana madrasah, 4) anggaran, 5) pergaulan siswa, serta 6) motivasi siswa.

Hasil penelitian ini sejalan dengan penelitian yang dilakukan oleh Yayan Budi Sofyan (2014) yang menunjukkan bahwa salah satu hambatan pelaksanaan pendidikan karakter adalah sulitnya mengajak seluruh elemen pendidik untuk melaksanakan pendidikan karakter. Murray Print (1993) menyatakan bahwa pendidik (guru) berperan sebagai implementer kurikulum yang sangat menetukan keberhasilan pencapaian tujuan kurikulum. Dengan demikian, keberhasilan pelaksanaan pendidikan karakter sangat tergantung pada komitmen dan kemampuan guru.

\section{KESIMPULAN}

Berdasarkan hasil penelitian ini, kesimpulan yang dapat diambil adalah sebagai berikut:

1. Pendidikan karakter di MAN 2 Palembang belum terlaksana secara maksimal. Beberapa hal yang belum dilaksanakan terkait pelaksanaan pendidikan karakter adalah: a) belum semua strategi pembelajaran kontekstual digunakan, b) belum semua guru menggunakan strategi pembelajaran kontekstual, c) belum ada upaya khusus untuk merevitalisasi kegiatan ko dan ekstra kurikuler, d) terkait pengintegrasiannya oleh guru dalam pembelajaran, masih ada 33,33\% guru melaksanakannya dengan kurang baik (20,8\% terkategori kurang baik pada aspek perencanaan 
pembelajaran, 25\% pada aspek pelaksanaan pembelajaran, dan 4,2\% pada aspek penilaian pembelajaran).

2. Banyak faktor kendala dan pendukung pelaksanaan pendidikan karakter di MAN 2 Palembang. Faktor kendala dari sisi madrasah meliputi: 1) kesulitan dalam melaksanakan kegiatan rutin, 2) kesulitan dalam melaksanakan kegiatan spontan, dan 3) kesulitan dalam melaksanakan kegiatan pengkondisian. Sedangkan faktor kendala dari sisi guru adalah kesulitan mengintegrasikan pendidikan karakter dalam proses pembelajaran, yang meliputi: 1) kesulitan mengaitkan pendidikan karakter baik dengan materi, metode, strategi, maupun media pembelajaran, 2) kesulitan menentukan nilai karakter yang akan dicapai, 3) kesulitan mengukur ketercapaian pendidikan karakter pada diri peserta didik, 4) jumlah siswa per kelas yang terlalu banyak, 5) belum semua guru dan karyawan bisa menjadi teladan, 6) banyaknya hal yang mempengaruhi karakter, serta 7) banyaknya aspek karakter yang harus dikembangkan. Sementara faktor pendukung pelaksanaan pendidikan karakter di MAN 2 Palembang meliputi: 1) dukungan seluruh warga madrasah, 2) lingkungan keluarga, 3) sarana prasarana madrasah, 4) anggaran, 5) pergaulan siswa, serta 6) motivasi siswa. 


\section{DAFTAR PUSTAKA}

Albertus, Doni Koesoema. 2010. Pendidikan Karakter Strategi Mendidik Anak di Zaman Global, Jakarta: PT.Grasindo.

Ali, Muhammad. 1985. Penelitian Kependidikan Prosedur dan Strategi. Bandung: Angkasa.

Bogdan, $R$ dan Taylor, S.J. 1975. Introduction to Qualitative Research Methode. New. York: John Willey and Sons.

Gunawan, Heri. 2012. Pendidikan Karakter Konsep dan Implementasi, Bandung:Alfabeta.

Kementrian Pendidikan Nasional, 2010, Pengembangan Pendidikan Budaya dan Karakter Bangsa, Bahan pelatihan penguatan metodologi pembelajaran berdasarkan nilai-nilai budaya untuk membentuk daya saing dan karakter bangsa, Jakarta

2011. Panduan Pelaksanaan Pendidikan Karakter, Jakarta: Badan Penelitian dan Pengembangan Pusat Kurikulum dan Perbukuan.

Khan, Yahya. 2010. Pendidikan Karakter Berbasis Potensi Diri, Yogyakarta: Pelangi Publishing.

Kusuma, Dharma. 2011. Pendidikan Karakter Kajian Teori dan Praktik di Sekolah, Bandung: PT. Remaja Rosdakarya.

Lickona, Thomas. 1992. Educating For Character: How Our School Can Teach Respect and Responsibility, New York:Bantam Books.

Nikawanti, Gia. 2015. "Pendidikan Karakter Disiplin pada Anak Usia Dini: Studi Kasus pada Kelompok Bermain Cikal Gemilang 2 Padalarang Bandung Barat", Tesis, Bandung: Universitas Pendidikan Indonesia.

Pertama, Devi Irena. 2015. "Pendidikan Karakter Melalui Pengasuhan untuk Membentuk Manusia Seutuhnya", Disertasi, Bandung: Universitas Pendidikan Indonesia 
Puskur, 2011. Pedoman Pelaksanaan Pendidikan Karakter. Jakarta: Balitbang Kemendiknas.

Samani, Muchlas \& Harianto. 2011. Pendidikan Karakter Konsep dan Model, Bandung: PT. Remaja Rosdakarya.

Sofyan, Yayan Budi. 2014. "Pendidikan Karakter dalam Upaya Penanggulangan Tawuran antar Pelajar di SMK Swasta", Tesis, Bandung: Universitas Pendidikan Indonesia.

Sutarno. 2008. Pendidikan Multikultural. Jakarta: Direktorat Jendral Pendidikan Tinggi Departemen Pendidikan Nasional.

Thalib, Syamsul Bachri. 2010. Psikologi Pendidikan Berbasis Analisis Empiris Aplikatif. Jakarta: Kencana. 